\title{
¿PATRIOTISMO O LEYENDA NEGRA? LA RECONQUISTA EN EL SIGLO XIX
}

\section{¿PATRIOTISM OR BLACK LEGEND? THE RECONQUISTA IN THE 19TH CENTURY}

\author{
Juan Pablo Domínguez* \\ Instituto Cultura y Sociedad, Universidad de Navarra, Pamplona, España
}

\begin{abstract}
RESUMEN: En el siglo XIX, la idea de España como antítesis de la Europa moderna era algo más que un arma de propaganda antiespañola, una expresión del complejo de inferioridad hispánico o un artículo del credo progresista. Era el gran tópico identitario español, compartido por todas las corrientes ideológicas, empezando por las más conservadoras e hispanófilas. Este artículo presenta diversos textos decimonónicos que atribuyen a la Reconquista la escasa inclinación de los españoles a la tolerancia, la industria y la ciencia. Y así evidencia que los autores más dispares no solo daban por cierta la distancia entre España y Europa, sino que asociaban esa distancia a la gesta originaria de la nación española.
\end{abstract}

PALABRAS CLAVE: leyenda negra, historiografía española, identidad nacional española, decadencia española, reconquista.

\begin{abstract}
In the 19th century, the idea of Spain as the antithesis of modern Europe modernity was not only a weapon of anti-Spanish propaganda, an expression of the Spanish inferiority complex or an article of the progressive creed: It was the leading premise of Spanish identity, shared by even the most hispanophile and conservative authors. This article examines a variety of 19th century texts which attributed Spain's backwardness to the Reconquista, insisting that the long wars with the Moors made the Spaniards less inclined to tolerance, industry and science than other Europeans. It thus shows that writers of that time, regardless of ideology, not only believed in the reality of Spanish backwardness, but associated it with the very origins of the Spanish nation.
\end{abstract}

KEYWORDS: Black legend, Spanish historiography, Spanish national identity, Decline of Spain, Reconquista.

* Correspondencia a: Juan Pablo Domínguez. Instituto Cultura y Sociedad, Universidad de Navarra, 31009 Pamplona-jdfernandez@unav.es - https://orcid.org/0000-0003-0814-9371

Cómo citar: Domínguez, Juan Pablo (2021). "¿Patriotismo o leyenda negra? La Reconquista en el siglo XIX»; Historia Contemporánea, 65, 7-40. (https://doi.org/10.1387/hc.21068).

Recibido: 8 agosto, 2019; aceptado: 5 diciembre, 2019.

ISSN 1130-2402 — eISSN 2340-0277 / (C) 2020 UPV/EHU 


\section{España es diferente: un consenso historiográfico}

Los apologistas de España han clamado en todo tiempo contra la «malicia de los extranjeros» que denigran a «nuestra grande nación». ${ }^{1} \mathrm{Y}$, al menos desde el siglo XVIII, contra aquellos españoles que, empeñados en el «abatimiento y deshonra de la nación», propagan las calumnias foráneas. $^{2}$

En la literatura española del ochocientos abundan las críticas a los extranjeros que desfiguran la imagen de España. ${ }^{3} \mathrm{Y}$ a los liberales autóctonos que, «con bajo servilismo y necia fruición», repiten los ultrajes a la patria de «la absurda crítica extranjera». ${ }^{4}$

A comienzos del siglo Xx, Julián Juderías llamó «leyenda negra»al tópico «de la España inquisitorial, ignorante, fanática, (...) enemiga del progreso y de las innovaciones». Y, aunque achacó su origen a la opinión extranjera, también insistió en que, «apenas iniciada la decadencia de nuestra patria», en la misma España salieron «por doquiera, como ahora», pesimistas dispuestos a irradiar la leyenda. ${ }^{5}$ No es de extrañar que la derecha reaccionaria adoptase las tesis de Juderías y acusara al liberalismo decimonónico español de importar la leyenda negra para deshacer la patria. ${ }^{6}$

En nuestros días empieza a advertirse el rol de los antiilustrados españoles en la construcción de la idea de España como antítesis de la Ilustración. ${ }^{7}$ Pero, en general, aún se atribuye a escritores británicos, franceses y alemanes la expulsión de España al «sur de la modernidad». ${ }^{8} \mathrm{Y}$ se insiste en que los liberales españoles del XIX asumieron la leyenda negra de origen foráneo. ${ }^{9}$

Yo creo, no obstante, que la idea de una leyenda negra pergeñada por extranjeros y reiterada después por progresistas españoles tiende a ocultar esta simple verdad: que también los apologistas de lo hispano han creído en esa España intolerante, alejada de Europa y reacia a la industria y a la ciencia.

No pretendo contrariar la corriente historiográfica que, desde mediados del siglo XX, presenta a España como un país europeo normal, con su

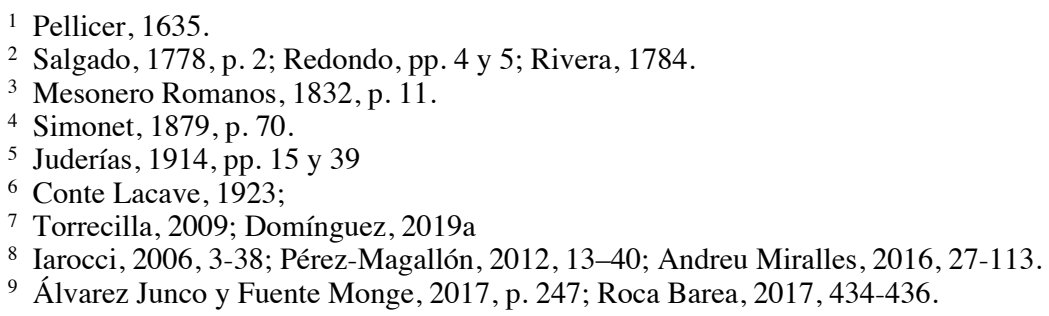


Ilustración, su capitalismo, sus aportaciones a la ciencia moderna y hasta su tradición de tolerancia religiosa. ${ }^{10}$ Aspiro simplemente a recordar que, si esa corriente surgió hace poco más de medio siglo, fue porque hasta entonces todos (españoles y extranjeros, apologistas y críticos) narraban una España divergente de Europa.

No me opongo, por tanto, a quienes defienden la modernidad española. $\mathrm{Ni}$ a quienes cuestionan la idea misma de modernidad. Doy por hecho que la España antimoderna es un país imaginario, opuesto a una quimérica Europa normal. Quiero únicamente resaltar que esa España antimoderna no solo la idearon sus críticos, sino también sus más rendidos partidarios.

Tomás Pérez Vejo ha dicho que, en sus rasgos esenciales, el «relato canónico sobre el ser de la nación española» fue común a liberales y conservadores en el siglo XIX. ${ }^{11}$ Pero esta opinión, que comparto, está lejos de ser predominante. Los estudiosos de la historiografía española acentúan casi siempre la disparidad narrativa de las «dos Españas». ${ }^{12} \mathrm{~A}$ veces reconocen la importancia de los relatos intermedios (a un tiempo liberales y conservadores) de autores como Modesto Lafuente. Pero raramente advierten que las historias progresistas, reaccionarias y liberal-conservadoras subrayaron al unísono la resistencia de España a eso que en el siglo XX se llamaría «modernidad». Es decir: al capitalismo, la secularización y la ciencia.

En realidad, no hubo dos ni tres relatos, sino muchos más. Si asumo aquí estas divisiones convencionales, y etiqueto a los diversos autores con adscripciones ideológicas a veces dudosas, es para mostrar que el mito de la «España antimoderna» fue común a las más diversas tradiciones políticas. Sé muy bien que no todos los historiadores del siglo XIX tuvieron una clara militancia, y que en un mismo bando cabían visiones del pasado muy diversas. Sé, por ejemplo, que, aunque Luis Morote y Rafael Altamira fueran republicanos de la misma generación, difícilmente se hallarán dos historias de España más dispares que la optimista y profesional de Altamira y la pesimista y diletante de Morote. Pero aquí no me interesan esas diferencias, sino el hecho de que hasta Altamira (precursor, según se dice, «de la tesis de la España "normal”») creyó en la inusual resistencia del tipo «tradicional de vida española» a las transformaciones de «la civilización moderna». ${ }^{13}$

10 Cañizares-Esguerra, 2006; Schwartz, 2008; Bianca, 2017.

11 Pérez Vejo, 2020, p. 45.

12 Álvarez Junco y Fuente Monge, 2017, pp. 266-282.

13 Altamira, 1950, p. 186; Álvarez Junco y Fuente Monge, 2017, p. 331. 
No voy a distinguir entre historia filosófica e historia erudita. Ni siquiera entre historia, periodismo y política. Son géneros diversos; pero todos engrosaron el mito de la excepcionalidad hispana. Tampoco subrayaré lo específico de la mirada extranjera, sino el hecho (con frecuencia olvidado) de que, a ambos lados de los Pirineos, los progresistas lamentaron la resistencia de España a la «modernidad» y los reaccionarios celebraron esa misma resistencia. ${ }^{14}$

Pasaré asimismo por encima de los cambios políticos e historiográficos que sufrió España a lo largo del siglo XIX. Fueron, sin duda, importantes; pero aquí pondré el foco en ciertas continuidades discursivas habitualmente ignoradas. No voy a discutir las tesis sobre el auge finisecular del nacionalcatolicismo y la angustia patriótica. Solo a subrayar que la idea de la distancia entre España y Europa fue un lugar común desde el siglo XVIII hasta el siglo XX.

En otra parte he mostrado cómo los apologistas dieciochescos de España la definieron frente a los valores ilustrados. ${ }^{15}$ Y cómo los adversarios de las Cortes de Cádiz (con su exaltación de la España antimoderna) anticiparon el nacionalcatolicismo de Menéndez Pelayo. ${ }^{16}$ Por lo que respecta al liberalismo decimonónico, basta abrir las historias de España del periodo isabelino para dar con el tópico de la excepcionalidad hispana. Modesto Lafuente, por ejemplo, comienza su Historia General de España destacando, entre los rasgos esenciales del carácter nacional, la religiosidad, el «instinto conservador» y el «apego al pasado». Y añade:

«[E]stas cualidades hacen de España un pueblo singular que no puede ser juzgado por analogía. Escritores muy ilustrados han incurrido en errores graves y hecho de ella inexactos juicios, no imaginando que pudiera haber un pueblo cuyas condiciones de existencia fuesen casi siempre diferentes, muchas veces contrarias a las del resto de Europa». ${ }^{17}$

Es bien sabido que, en el siglo XIX, la distancia entre España y Europa solía atribuirse a la Inquisición y al despotismo de los Austrias. Aquí quiero mostrar que, para muchos escritores de entonces, también la Reconquista había alejado «la civilización española de la europea».

\footnotetext{
${ }_{14}$ Maistre, 1822; Morel, 1857; von Hefele, 1860; André, 1922; Walsh, 1930.

15 Domínguez, 2019a.

16 Domínguez, 2019b.

17 Lafuente, 1950, v. I, p. 12.
} 
«Por ella», escribió Fermín Gonzalo Morón, «es la historia de España tan nueva y tan original, y por ella también ha sido calumniado con ligereza y precipitación nuestro país, y aún hoy mismo es tan mal comprendido de los extranjeros. Aplicar las ideas y principios sobre gobierno de Europa para juzgar sus hechos pasados y pensar en la organización de hoy, será siempre eterno semillero de errores y desaciertos». ${ }^{18}$

En realidad, los hispanistas foráneos apenas diferían de Morón en este punto. Mi artículo quiere mostrar, precisamente, que los relatos patrióticos no siempre se distinguieron de la «leyenda negra»; que españoles, extranjeros, apologistas y críticos coincidieron en vincular la excepcionalidad de España a sus orígenes históricos y a sus más indisputadas glorias.

Digo indisputadas porque en esto disiento de Jesús Torrecilla, para quien los progresistas españoles del XIX no vieron en la Reconquista una «hazaña gloriosa, sino una dolorosa tragedia». Es verdad (como dice Torrecilla) que muchos progresistas incluyeron la guerra contra los «moros» entre las causas de la decadencia nacional. ${ }^{19}$ Pero no lo es menos que, en general, juzgaron la conquista islámica como «la mayor catástrofe que sufrió España». ${ }^{20} \mathrm{Y}$ que no renunciaron a celebrar ni el alzamiento de Pelayo ni el definitivo triunfo cristiano. Más aún: dado su rechazo a la monarquía de los Austrias, la Reconquista se convirtió para ellos en la gloria nacional por excelencia. ${ }^{21}$

También fuera de España se cantaron las gestas del Cid y de Pelayo. Puede extenderse a los hispanistas europeos lo que Ivan Jáksic ha dicho de los norteamericanos: que vieron la Reconquista como «la época más gloriosa de España» y, a la vez, como el origen de ese «temperamento marcial» y esa fe «en la santidad de su causa» que (al degenerar en «fanatismo ciego» y «tendencia cruel y belicosa») alejaron a los españoles de la senda del progreso. ${ }^{22}$

\section{Reconquista y decadencia}

En el siglo XVIII, William Robertson definió a los reconquistadores como hombres sin más artes que la guerra y Voltaire los acusó de conver-

18 Morón, 1842, v. III, pp. 8-9.

19 Torrecilla, 2016, pp. 46, 156 y 167.

20 Morayta, 1893, v. I, p. 633.

21 Castelar, 1876, p. 127; Castro, 1877, p. XXIV; Rodríguez Pinilla, 1879, v. II, pp. 247-248; Tubino, 1886, p. 74; Ortega Rubio, 1889, v. I, p. 109 y v. II, p. 54.

22 Jaksić, 2007, pp. 17-18. 
tir a España en «une nation qui ne savait que combattre». ${ }^{23}$ También los ilustrados españoles dijeron, una y otra vez, que el continuo batallar contra los árabes «nos enemistó con las artes, con los oficios y aun con las ciencias». ${ }^{24}$

Estas opiniones ganaron adeptos en el siglo XIX. Solo unos pocos historiadores, como el uruguayo Francisco Bauzá, absolvieron a la Reconquista de toda culpa. Hispanófilo a fuer de conservador y de católico, Bauzá atribuyó la decadencia a causas enteramente posteriores a la conquista americana. Y así pudo celebrar sin matices el legado de la Reconquista:

«La reacción contra el moro, empezando entre las breñas de Asturias para concluir en el asalto victorioso de Granada, concretó para los españoles durante setecientos años los más nobles objetivos que pueden interesar el corazón humano, sin distraerlo un día de esa tensión imperiosa. Por eso fue que al nacer como gran nación ante Europa, llevaban consigo el sello de la originalidad, uniendo al temple varonil y la disposición aventurera de que habían dado muestras, las prácticas de buen gobierno y la aptitud industrial que parecían opuestas a aquellas cualidades». ${ }^{25}$

Más entusiasta aún fue el regeneracionista español Ricardo Macías Picavea. Para él, la decadencia se debió exclusivamente al «teutón Carlos $\mathrm{V} »$, que de golpe extinguió «las grandezas y virtudes» que España había templado en ocho siglos de «sin igual lucha»:

«[L]a monarquía democrática, el municipio republicano, un pueblo rival del romano en ser a la vez cives - dueño de sus destinos en el Concejo- y miles in procintu - defensor de su patria grande y chica en las comunales milicias-; un self government cual no le posee hoy país alguno; (...) una burguesía inteligente, laboriosa, rica y creadora de todo linaje de empresas mercantiles e industriales; unos gremios de menestrales que pesaban tanto o más que la nobleza en la vida pública; un 111 .

${ }^{23}$ Robertson, 1769, v. I, p. 145; Voltaire, 1756, v. II, p. 296 y 1761, v. IV, pp. 109-

${ }^{24}$ Graef, 1755, pp. 27-29, 1-72; Rodríguez Mohedano y Rodríguez Mohedano, 1766, p. LXXVI; Masdeu, 1783, v. I, pp. 84-85 y 167-168; «Adiciones al artículo España», 1792, p. 100; Cadalso, 1793, p. 11; Forner, 1844, p. 227; Arroyal, 1971, p. 170; José de Vargas Ponce, cit. en Pérez-Magallón, 2012, p. 32.

25 Bauzá, 1895, v. I, p. 8. 
justicia de Aragón y un Consejo de Castilla que recuerdan la censura en Roma y el Areópago en Atenas; unas Cortes, en fin, que todavía, en nombre de los grandes intereses nacionales, intervenían el poder que al Rey quedaba fuera de los señoríos, fueros, behetrías y municipalidades libres». ${ }^{26}$

Sin embargo, para el grueso de la historiografía decimonónica, la Reconquista no solo originó las libertades medievales y el Imperio hispánico, sino también la intolerancia inquisitorial y la escasa inclinación de España a la ciencia, la industria y el comercio. ${ }^{27}$

Algunos historiadores relevantes llegaron a afirmar que, lastrada como estaba por la Reconquista, España no descolló en lo económico ni aun con los Reyes Católicos. Esta tesis, que negaba la decadencia de España al negar también su auge, se ha atribuido a los «prejuicios» de Leopold von Ranke «sobre la naturaleza de los españoles»; pero lo cierto es que su gran divulgador fue Antonio Cánovas del Castillo. ${ }^{28}$ Ranke consideró que la precariedad demográfica y comercial era la condición natural de Castilla y atribuyó los defectos económicos de sus habitantes (el culto a la hidalguía y el desprecio al trabajo) a la distinción entre liberadores y liberados surgida en la Reconquista. Pero también vio en la guerra con los «moros» el origen de las excelencias de la Corona de Aragón: la constitución aragonesa, la agricultura valenciana y el comercio marítimo catalán. ${ }^{29}$ Cánovas se opuso sin matices a quienes creían «muy desahogado el tesoro público y muy florecientes las artes, el comercio y la agricultura» en tiempos de los Reyes Católicos:

«¿Qué industria ni qué comercio, ni qué maravillas en la agricultura, podían alcanzar tales pueblos que habían vivido ocho siglos lidiando de provincia a provincia, de pueblo a pueblo, de heredad a heredad? ¿Cómo habían de ser fabricantes ni comerciantes hombres a quienes no daba descanso un solo día el ejercicio de la espada?» ${ }^{30}$

26 Macías Picavea, 1898, pp. 318-319.

27 Macaulay, 1843, v. II, p. 167; v. III, pp. 222-223; Morón, 1842, p. 137; 1844, pp. 147-149.

28 Gascón Pérez, 2007, p. XXI.

29 Ranke, 1845, pp. 121-127.

30 Cánovas del Castillo, 1854, p. 8. 
La obsesión decimonónica con el «carácter nacional» afectó de lleno al relato de la Reconquista. Se hizo costumbre atribuirle el «temple belicoso» de la «nacionalidad española». ${ }^{31}$ Y eso no fue siempre celebrado: al menos desde el siglo XVIII, la decadencia de España se achacaba precisamente a su «espíritu de conquista». ${ }^{32}$

Hacia 1844, el célebre apologista católico Jaime Balmes lamentó que «siete siglos de combate» hicieran de España «la nación más belicosa del mundo», llevándola a perder sus antiguas «instituciones democráticas». ${ }^{33}$ Carlistas como Víctor Gebhardt repitieron luego esta ideas sobre el influjo de «ocho siglos de combate» en la «pérdida de nuestras antiguas y venerandas libertades». 34

El historiador argentino José Manuel Estrada, hispanófilo y militante de la Unión Católica, escribió que la «restauración española» (al nivelar la sociedad y poner las armas «en manos del pueblo») engendró esa «libertad de las comunidades» a cuya sombra florecían «la industria y el comercio». Pero señaló asimismo que «la guerra tenaz y heroica de la redención nacional» infundió «en los pechos de hierro de aquellos varones, más potentes con el mandoble que con el pensamiento», dos «pasiones dominantes y arraigadas» que serían para España «a la vez su gloria y su desgracia»: el «fanatismo religioso» y el «espíritu de conquista». A este último achacaba Estrada el despotismo de la España de los Austrias:

«Educada en la guerra, formada al calor de la batalla y la victoria, dejose fascinar por mentirosos ensueños de poderío y grandeza (...) La educación guerrera del pueblo español y la desinteligencia de sus clases, pusieron la espada en manos del monarca y abrieron el camino a la usurpación». .35

También Cánovas y sus adeptos subrayaron el carácter «impolítico y funesto» del sueño imperial de España. ${ }^{36}$ Manuel Danvila y Collado, escribió que los triunfos de «ocho siglos de combates» engrieron a la España moderna, confiriéndole un distintivo «espíritu caballeresco» y empujándola a una «no interrumpida serie de guerras» que le impidieron

\footnotetext{
31 Morón, 1842, p. 137; Cánovas del Castillo, 1863, p. 65.

32 Rodríguez de Campomanes, pp. 411-412.

33 Balmes, 1844, v. IV, pp. 183-184.

34 Gebhardt, 1864, v. IV, p. 429.

35 Estrada, 1896, v. I, pp. 2-24.

${ }^{36}$ Cánovas del Castillo, 1868, p. 154.
} 
«cuidar sus negocios» y derramaron «con prodigalidad excesiva» los «tesoros y la sangre de los españoles» por Europa, Âfrica y América. ${ }^{37}$

Lo mismo, aunque en tono más agónico, dijeron los regeneracionistas del fin de siglo. Ángel Ganivet insistió en que las energías nacionales se habían «gastado en empresas heroicas» y atribuyó el «espíritu quijotesco» de los españoles a «la tragedia de la Reconquista», que los convenció «de que el mundo era el campo de un torneo, abierto a cuantos quisieran probar la fuerza de su brazo». ${ }^{38}$

También se dijo, una y otra vez, que los reconquistadores despreciaron «todas las artes que no tenían relación con la guerra», de modo que la España cristiana no tuvo «ciencias, ni artes, ni industria» y «fue más ignorante que el resto de la Europa». ${ }^{39}$ El republicano Francisco Guillén Robles lamentó que la Reconquista engendrase una «multitud de aventureros» enriquecidos «con las propiedades de los vencidos», una «muchedumbre de gente baldía y belicosa, no muy acostumbrada al trabajo».$^{40} \mathrm{El}$ progresista Ramón Pasarón Lastra situó el origen del atraso industrial de España en los ocho siglos de guerra contra los árabes, que acentuaron el «espíritu marcial y guerrero» de los godos y el consiguiente desprecio a «las profesiones pacíficas» como «indignas del hombre elevado». ${ }^{41} \mathrm{El} \mathrm{ca}$ novista Danvila y Collado atribuyó el declive económico del siglo XVII a que «ocho siglos de lucha y de guerra con los moros habían apartado a los españoles del ejercicio de las artes de la paz». ${ }^{42}$

En 1854 Cánovas atribuyó la decadencia nacional a los «gérmenes de corrupción» que España arrastraba desde la Reconquista: el fanatismo religioso, el provincialismo, la despoblación y la pobreza. ${ }^{43}$ Dos décadas más tarde, insistió en que la decadencia se debía a «la enorme desproporción que siempre hubo entre nuestros escasos recursos interiores, y las múltiples y vastas empresas en que nos fuimos empeñando». Y presentó esta escasez de recursos como resultado de «la devastación forzosamente causada por ocho siglos de una guerra intestina». ${ }^{44}$

37 Danvila y Collado, 1885, v. II, pp. 468-469.

38 Ganivet, 1897, p. 78; Ganivet, 1898.

39 Blanco White, 1825, p. 21; Morón, 1841, v. I, p. 32; Ríos, 1843, p. 152; Ríos, 1848 , p. 24; Lafuente, 1852, v. IX, pp. 217-218; Ortega Rubio, 1889, v. I, p. 228.

${ }^{40}$ Guillén Robles, 1880, pp. 174 y 365.

41 Pasarón Lastra, 1857.

42 Danvila y Collado, 1885, v. II, p. 172.

43 Cánovas del Castillo, 1854, pp. 4-9.

44 Cánovas del Castillo, 1868, p. 154. 
También los extranjeros atribuían a la Reconquista la decadencia económica de España. Uno de los más categóricos fue el norteamericano Henry Charles Lea:

«There is a pride which spurs nations on to great achievements, which reckons nothing done while aught remains to do, and which wisely adapts means to ends. Such was not the pride of Spain: it was proud of what it had done, and imagined that its superiority to the rest of the world left it nothing more to do; it could learn nothing and forget nothing; it had varied the centuries of the Reconquest with endless civil broils, while it left the arts of peace to subject Moors and Jews, until honest labor was regarded with disdain, and trade and commerce were treated in a barbarous fashion that choked all the springs of national prosperity». ${ }^{45}$

A finales de siglo, también la «decadencia de la raza» se imputó a la Reconquista. El peruano Clemente Palma atribuyó al gasto de «fuerzas nerviosas» contra los «moros» el abismo racial que separaba a «los Cides y Pelayos» de los «fanáticos y aventureros» que habían legado a Hispanoamérica su incapacidad para la «civilización progresiva». ${ }^{46}$

\section{La Reconquista y el fanatismo español}

Liberales y reaccionarios tenían opiniones encontradas sobre la intolerancia religiosa. Pero unos y otros la creían más prevalente en la historia de España que en la de Europa. Y vinculaban esa mayor prevalencia a los ocho siglos de la Reconquista.

Por supuesto, hay una enorme diferencia entre un antiilustrado que celebra la pervivencia de «aquella como divisa de nuestra nación, guerra contra infieles», y un anticatólico que deplora el «feroz fanatismo» legado a España por la Reconquista. Pero, más allá de los juicios de valor, sus narrativas comparten esta trama vertebral: la guerra con los «moros» engendró la intolerancia española. ${ }^{47}$

La misma trama aparece, una y otra vez, en los relatos de España del siglo XIX ${ }^{48}$ En Alemania, los románticos conservadores lamentaron la en-

\footnotetext{
${ }^{45}$ Lea, 1989, pp. 36-46.

46 Palma, 1897, p. 16.

47 Fernández Valcarce, 1797, p. 449; Blanco White, 1824, p. 108.

48 Bouterweck, 1805, v. III, pp. 149-154; Schlegel, 1829, v. II, p. 193.
} 
vidiosa ingratitud de los modernos europeos, que condenaban la fiera religiosidad hispana sin advertir que había nacido en los largos siglos en que España, a más de luchar por su patria y religión, fue vanguardia de Europa ante el Islam. ${ }^{49}$ En Francia, los reaccionarios católicos celebraron que la Reconquista preparase a España para defender a Europa del protestantismo. Y alentaron a los españoles a armarse de nuevo con la cruz y la espada para librarse de la revolución «comme elle s'est délivrée de l'Islamisme» y retomar la «mission mystérieuse» que Dios les había encomendado en la Edad Media. ${ }^{50}$

Por su parte, los progresistas de Europa y América condenaron el espíritu fanático y conquistador que había precipitado la decadencia de España. ${ }^{51}$ Charles de Villers, en su libro sobre las raíces protestantes de la superioridad norteuropea, exculpó de este modo la opción de Carlos V por la contrarreforma:

«Ses sujets d'Espagne, où l'inquisition venait d'être introduite, et où la longue terreur inspirée par les Maures avait entretenu le peuple dans le catholicisme le plus superstitieux, se seraient à l'instant révoltés contre lui s'il eût paru catholique moins zélé qu'eux». ${ }^{52}$

El célebre historiador whig Thomas Babington Macaulay describió la existencia de España como una larga cruzada y atribuyó a la Reconquista el singular celo religioso de los castellanos: ocho siglos de lucha contra el invasor islámico habían unido inseparablemente la religión de sus ancestros con las instituciones, la independencia y la gloria de su patria. ${ }^{53} \mathrm{~A}$ esa identidad entre catolicismo y España atribuía Macaulay el auge de la Monarquía Hispánica en el siglo XVI, pero también el fanatismo que la mantuvo en una suerte de prolongada infancia:

«Among the men of the seventeenth century he was the man of the fifteenth century, or of a still darker period -delighted to behold an Auto $d e f e$, and ready to volunteer on a crusade». ${ }^{54}$

49 Schlegel, 1815, v. II, pp. 340-341.

50 Pitra, 1846, pp. XVIII-XIX; Morel, 1857, pp. 149, 155 y 293; Veuillot, 1860, p. 179; Pitra.

51 Jaksić, 2007, pp. 17-18.

52 Villers, 1804, p. 56.

53 Macaulay, 1843, v. III, pp. 222-223.

54 Macaulay, 1843, v. II, p. 167. 
En las primeras páginas de Ferdinand and Isabella, el historiador norteamericano William H. Prescott afirma que las guerras con el infiel multiplicaron la influencia de los eclesiásticos, encendieron el «religious enthusiasm» de los españoles, y los llevaron a creer en toda clase de milagros y a sentirse el pueblo elegido:

«Hence the national character became exalted by religious fervor, which in later days, alas! settled into a fierce fanaticism. Hence that solitude for the purity of faith, the peculiar boast of the Spaniards, and that deep tingle of superstition, for which they have ever been distinguished above the other nations of Europe». ${ }^{55}$

En History of the Reign of Philip II, Prescott reforzó la imagen de Felipe II como encarnación del fanatismo y máximo culpable de la decadencia española. No obstante, vio en su hostigamiento a los moriscos un nuevo capítulo de una guerra de más de ocho siglos que no acabaría hasta el «exile or extermination of the conquered race». ${ }^{56} \mathrm{Y}$ en su ruinosa guerra contra el protestantismo en Europa, una continuación de viejas tradiciones medievales:

«The Romish faith may be said to have entered into the being of the Spaniard. It was not merely cherished as a form of religion, but as a principle of honor. It was part of the national history. For eight centuries the Spaniard had been fighting at home the battles of the Church. Nearly every inch of soil in his own country was won by the arms from the infidel. His wars, as I have more than once had occasion to remark, where always wars of religion. He carried the same spirit across the waters. There he was still fighting the infidel. His life was a long crusade. How could this champion of the Church desert her in his utmost need? $\gg^{57}$

Las opiniones de Prescott fueron, más o menos, las de todo el hispanismo liberal. Así explicaba un historiador francés los orígenes de la España inquisitorial, expansionista y pobre:

«Après six siècles d'un lutte pour l'existence, soutenue contre l'islamisme, les Espagnols en étaient venus à confondre en un seul amour

\footnotetext{
55 Prescott, 1838, pp. XXXVIII, XXXIX, LXV, LXVI.

56 Prescott, 1858, v. III, p. 235.

57 Prescott, 1856, v. I, p. 472.
} 
la patrie et la religión, et à ne regarder comme útiles à la nation que le soldat et le prétre; de là l'horreur du changement, puisque la religión répond à tous les besoins, et le mépris du travail, puisque la guerre est la première nécessité de la vie».

Según esto, Felipe II fue «un obstacle dans la marche de la civilisation», pero no un monstruo inexplicable. Su política se ajustó «aux instincts de son peuple», heredados de la larga lucha contra los musulmanes. $\mathrm{Y}$ esos instintos ancestrales hicieron de la Inquisición «une institution nationale», y de la industria «un objet de dédain».58

Los reaccionarios españoles, por su parte, veían a España como «la nación católica por antonomasia», que «por espacio de siete siglos luchó por su fe y por su independencia» y acabó convertida en «paladín constante del catolicismo contra la herejía». ${ }^{59} \mathrm{La}$ «noble y salvadora intolerancia» de la España de los Austrias les parecía una prolongación de los ocho siglos de batallas que habían teñido el brazo español «en sangre mora». ${ }^{60}$

Los enemigos de la libertad de conciencia evocaron el pasado de España para recordar que «la historia y los sucesos establecieron entre nosotros la unidad de religión». ${ }^{61}$ Promover la libertad de cultos equivalía «a rasgar la bandera española, a borrar nuestra gloriosa historia, en la que descuella como el hecho más culminante la lucha de ocho siglos contra el mahometismo». ${ }^{62}$ Balmes escribió:

«Oprímese el alma con angustiosa pesadumbre al solo pensamiento de que pudiera venir un día en que desapareciese de entre nosotros esa unidad religiosa, que se identifica con nuestros hábitos, con nuestros usos, nuestras costumbres, nuestras leyes, que guarda la cuna de nuestra monarquía en la cueva de Covadonga, que es la enseña de nuestro estandarte en una lucha de ocho siglos con el formidable poder de la media luna». ${ }^{63}$

En 1855, cuando ese día parecía acercarse, el moderado Pedro José Pidal recordó que la historia española no era como la de Francia, Inglaterra y otros

\footnotetext{
58 Forneron, 1882, v. IV, pp. 299-301.

59 Fuente, 1873, v. V, pp. 10 y 185.

60 Menéndez Pelayo, 1880, v. I, p. 25.

61 Pidal, 1875, p. 28.

62 «Comentarios al Concordato», 1851.

63 Balmes, 1842, v. I, p. 190.
} 
países con libertad de cultos: aquí hubo «ochocientos años de no interrumpidos combates», debidos «exclusivamente al sentimiento religioso», que habían dejado una «honda y profunda huella» en el «carácter nacional». ${ }^{64}$ En 1876, el duque de Almenara Alta se opuso a la tolerancia religiosa decretada en la constitución de Cánovas recordando la constante «tendencia de este pueblo» al «exterminio de sectas contrarias» e insistiendo especialmente en que «el afán del logro de esta unidad religiosa» fue «el ideal de las huestes de Pelayo», «de los cristianos en época del Cid», «de los españoles en los días de Isabel» y, en general, de toda la «falange de héroes» que, en «ocho siglos de incansable porfía», «reconquistaron el suelo y restauraron la nación» limpiando «de árabes el suelo patrio», desde «la peña de Covadonga hasta los muros de Granada», y legando a sus descendientes el «ideal de la unidad de culto». Esta «herencia sagrada» (unida a España «en la prosperidad y en la desgracia» y destinada a perdurar «en tanto que la Nación subsista y viva») necesariamente la enfrentaba a los países del «norte de Europa», dominados por la «raza germánica» y el «libre examen». ${ }^{65}$

En el discurso reaccionario, la unidad religiosa no solía ser efecto de la Reconquista, sino al revés: era la «unidad católica», proclamada por Recaredo, la que «hizo posible la Reconquista» y fue «durante ocho siglos de tenaz y sangrienta lucha el lazo que unió a los españoles». Pero, a su vez, la Reconquista había fortalecido ese «sentimiento de la unidad católica» hasta convertirlo en «el rasgo más característico de la nación». ${ }^{66}$

Para el jesuita Ricardo Cappa, la Reconquista introdujo «novedades de cuantía» en el catolicismo español: las necesidades de la guerra aunaron en las órdenes militares la potestad civil, militar y eclesiástica; y las necesidades de la repoblación dieron a iglesias y monasterios la jurisdicción civil y criminal sobre villas y pueblos. Para Cappa, ese consorcio del poder civil y el religioso estaba en el origen de la Inquisición y, con ella, de la depuración «de las nieblas y fétidos miasmas de la herejía» que lanzó a España a aquellas luchas contra Inglaterra, Francia, Holanda y Alemania en que «caímos acribillados de heridas» tras clavar, «entre charcos de sangre hispana», la bandera del catolicismo en media Europa ${ }^{67}$

64 Pidal, 1875, p. 16.

65 Discurso de José María Martorell y Fivaller, Diario de las Sesiones de Cortes. Congreso de los Diputados, 28 de abril de 1876, pp. 972-985.

66 «Comentarios al Concordato», 1851; Martínez de Irujo y del Alcázar, 1868, pp. 297-298; Polo y Peyrolón, 1904, pp. 14-15.

67 Cappa, 1888, pp. 44-46, 200 y 202. 
Frente al entusiasmo reaccionario, los liberal-conservadores se debatieron entre la celebración y la condena de la intolerancia española. Para Francisco Martínez de la Rosa, el sentimiento religioso había «predominado en la sociedad española mucho más que en ninguna nación europea», inspirando «obras inmortales» como el «descubrimiento y conquista» de América, pero dando también «margen a los excesos y extravíos de la superstición y el fanatismo». Y todo ello se explicaba por el «grandísimo influjo» de la Reconquista en las instituciones, leyes y costumbres de España:

«Formose su carácter durante la contienda, como se templa el hierro con los golpes que recibe el yunque, y el sentimiento religioso, probado y robustecido con la lucha y la resistencia, cobró necesariamente más tenacidad y pujanza». ${ }^{68}$

Fermín Gonzalo Morón vio en la «unidad católica» el «primero y más sólido cimiento de nuestra organización política». Y, aunque lamentó los males causados por la Inquisición «en el orden intelectual, material, y aun moral», juzgó su establecimiento una «fatalidad inevitable», «resultado necesario de hechos anteriores» y «del carácter del pueblo español». Morón ya apreciaba en tiempos de los godos la preponderancia de un sentimiento religioso «exclusivo y perseguidor». Preponderancia que, en su opinión, alcanzó el cenit con la lucha de «ocho siglos continuos sin descanso ni tregua» que convirtió el catolicismo en «la pasión más vehemente del pueblo español»:

«¿Cómo pues una sociedad formada así había de tolerar nada que no fuese aquella religión, que había sido su consuelo y esperanza en la desgracia y a la cual atribuían su reciente fortuna y engrandecimiento?». ${ }^{69}$

Modesto Lafuente celebró «el principio religioso» que «había inflamado el corazón de los españoles» por «espacio de ocho siglos», convirtiendo la «unidad católica» en el «alma de la política» española; pero lamentó «el fanatismo engendrado por la lucha religiosa de tantos siglos». Estimó que España debía su «gran retraso en la vía de la civilización» al establecimiento de la Inquisición y a la expulsión de los judíos, pero jus-

68 Martínez de la Rosa, 1841, pp. 315-316.

69 Gonzalo Morón, Fermín, 1844, pp. 147-149. 
tificó ambas medidas como contribuciones a la «unidad religiosa tan necesaria para afianzar la unidad política» y como inevitables concesiones a un pueblo que se había vuelto «fanático y supersticioso con tantos años de pelear en guerras de religión». ${ }^{70}$

José Amador de los Ríos insistió en que «el elemento teocrático», alimentado durante siglos de lucha contra «los sectarios de Mahoma», «todo lo había invadido, todo lo había sujetado a su carro triunfante, desde principios del siglo XVI». ${ }^{71}$

Antonio María Fabié escribió que la Reconquista arraigó la fe «de una manera profundísima» en España y, por eso, «cuando se inició en el norte de Europa la reforma, nuestra patria no tomó parte alguna en aquel portentoso movimiento que agitó a la mayor parte de la Europa» y afectó a «todos los órdenes del desenvolvimiento humano». Porque un pueblo formado en ocho siglos de una guerra «sobre todo religiosa» no podía sino templar sus armas «para defender en Europa el catolicismo amenazado» y aplaudir el rigor de la Inquisición contra quienes «iban delante de los demás por el camino de la ciencia». Y así «nuestra excesiva fe» trajo, como consecuencia natural, «la paralización absoluta del movimiento científico» en España. ${ }^{72}$

A mediados del XIX, Cánovas del Castillo lamentó el fanatismo que había alejado a España de «todas las naciones de Europa» al propiciar «la emigración de muchos miles de moros y judíos y luteranos expulsos o perseguidos del Santo Oficio», «la parálisis de todas las ciencias» y «el descaecimiento del carácter de la nación». Cánovas no excusó la ceguera de los reyes, que no acertaron a «aminorar en tanto como se pudo las llagas de la monarquía». Pero se opuso a quienes, «con escaso juicio», atribuían la intolerancia española a los monarcas extranjeros de la Casa de Austria. ${ }^{73}$ Para el entonces joven historiador malagueño, la «exageración del principio religioso» no solo era un rasgo autóctono, sino el origen mismo de la nación española:

«Hija legítima era de nuestra patria semejante exageración, si ya no es que digamos que fue su madre. Ni podía ser de otra suerte. Un na-

70 Lafuente, 1853, v. XI, pp. 58, 65 y 459; Discurso de Modesto Lafuente, Diario de las sesiones de las Cortes constituyentes, 9 de febrero de 1855, pp. 1359-1360.

71 Amador de los Ríos, 1848, p. 514.

72 Fabié, 1859, p. 8.

73 Cánovas del Castillo, 1854, pp. 5, 10 y 120. 
ción que peleó ochocientos años contra hombres que profesaban distinta creencia; que llevaba la cruz en todas sus banderas; y miraba a la religión hermanada con todas sus glorias; cuyo grito de guerra era un grito religioso; cuyos soldados estaban hechos a ganar indulgencias en las batallas, a obtener absolución de sus culpas muriendo en el campo, a sentir en su ayuda espadas de santos; cuyos obispos y sacerdotes eran guerreros; cuyos príncipes y princesas solían ser monjes, tenía necesariamente que colocar sobre todos los intereses el interés de la cristiandad, y anteponer la idea mística a toda idea política o literaria. Y esa nación misma, acostumbrada a defender su fe en las armas y a imponerla con la fuerza a los vencidos, acostumbrada a mirar en los infieles a su Dios, enemigos eternos, cuya muerte era, no solo lícita sino loable, y cuya vida era afrenta suya, cuando no pecado, tenía que ser intolerante hasta el extremo de constituir la inquisición, y hasta el punto de entrometerse en todas las guerras religiosas del mundo (...) Y ahora cúlpese cuanto se quiera aquel fanatismo religioso por el cual hubo España, y sin el cual no la habría; cúlpese al fanatismo que guio a los guerreros cristianos desde la cueva de Covadonga y el monte Pano hasta las puertas de la Alhambra; cúlpese a nuestra nación por lo que era, por lo que debía ser, por lo que el tiempo y los sucesos mandaban que fuese». ${ }^{74}$

Hacia 1868 Cánovas escribió que el «violento desarrollo» en la España del siglo XVI de aquel «espíritu de intolerancia» que secó la inteligencia del país con «la sistemática represión de las ideas» y llegó a «constituir el hecho culminante y decisivo de nuestra historia» no debía nada a Felipe II, sino al «sentimiento de la mayoría inmensa de la nación, sin diferencia de clases»:

«Esta nación nuestra había ya combatido, durante muchos siglos, a las razas extranjeras que sustentaban la religión mahometana con las armas (...) Vencidas, sometidas, destruidas ya en gran parte (...) fácil era que volviese luego su furor contra los disidentes del culto cristiano, que comenzaba a abrigar en su seno». ${ }^{75}$

El canovista Danvila y Collado juzgó ambiguamente la «unidad religiosa, que fue durante siglos bandera de la Reconquista». Por una parte, la celebró como indispensable para la unidad política de España y la subsistencia del catolicismo en Europa; por otra, lamentó que (al propiciar la In-

74 Cánovas del Castillo, 1854,p. 4.

75 Cánovas del Castillo, 1869, p. 22. 
quisición y la expulsión de los judíos) alejase a España del «movimiento intelectual europeo» y dañase su agricultura, su industria y su comercio. En su opinión, los españoles habían librado una guerra de ocho siglos en que «los enemigos de su fe eran también los enemigos de su independencia» y eso había hecho que «la fe católica y la nacionalidad española se confundieran hasta el punto de que se hizo España el representante por excelencia del catolicismo». De ahí las «guerras y aventuras» que luego (con «la fe que le inspiraba su perseverancia y el resultado de ocho siglos de lucha con los árabes») emprendió para «imponer sus creencias católicas a todo el mundo»; una «santa empresa» que «acabó con nuestros recursos y nuestra vida y labró nuestra desventura y ulterior decadencia». ${ }^{76}$

Los progresistas eran, por lo general, más rotundos en sus condenas a la intolerancia española. Y más amargos en sus lamentos por la decadencia nacional. En 1825, el antiguo afrancesado Pablo Mendíbil escribió desde su exilio londinense:

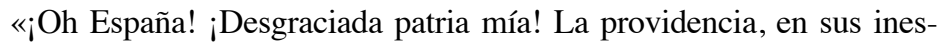
crutables designios, quiso sujetarte a mantener heroicamente en ocho siglos y a rematar con gloria al cabo de ellos, una guerra de religión, la más tenaz y bien reñida que ofrece la historia del género humano. Tus proezas, tus triunfos, tus virtudes mismas debían hacerte fanática e intolerante. Lo fuiste, y convirtiendo contra tus entrañas el celo indiscreto con que te hallabas connaturalizada, te has gozado en la opresión, te has glorificado en la tiranía, que aún hoy te tiene puesta al borde del abismo». ${ }^{.7}$

A mediados de siglo, Adolfo de Castro quiso escribir «la historia de España casi al revés de como hasta ahora se ha hecho». Se ha dicho que importó la «leyenda negra» extranjera, pero en realidad fue más radical que los hispanistas foráneos en su crítica a los Reyes Católicos («ciegos con el triunfo de sus armas en la guerra con el moro»), al «ignorante vulgo» de España y a los vencedores de la Reconquista en general. ${ }^{78}$ En su opinión, cuando los árabes «invadieron a España» se comprometieron a tolerar el culto cristiano y «cumplieron fielmente su promesa». Por el contrario, los «fanáticos vencedores» cristianos violaron en seguida las capitulaciones hechas con los «moros» tras reconquistar Toledo:

\footnotetext{
${ }^{76}$ Danvila, 1885, v. I, pp. 344, 536, 546, 572; v. II, pp. 227, 244, 442-443 y 491.

77 Mendíbil, 1826, p. 62.

${ }^{78}$ Castro, 1852 pp. VI, 10, 11, 13-15, 18, 24; López Vela, 2005, pp. 171-199.
} 
«Creció con tan inicuo ejemplo la intolerancia. Ya no se contentaban los cristianos con vencer a los moros por medio de las armas, sino que haciendo un infame uso de la victoria, los compelían a convertirse a la fe de Cristo». ${ }^{79}$

Según Castro, el fanatismo que arruinó a España y la dejó «en blanco en el mapa intelectual de Europa» nació con los clérigos de la Reconquista, que ansiaban «enriquecerse con los más preciados despojos de las batallas y de las presas de las ciudades». Con sus prédicas lograron «astutamente convertir en guerra de religión lo que solo tuvo origen en el deseo de recuperar los españoles la tierra de sus padres, usurpada por un poderoso ejército extranjero». Pronto inflamaron «los ánimos de la plebe» y convencieron a los reyes reconquistadores, desde Fernando III, iniciador del «uso de quemar a los llamados herejes», hasta Isabel I, que «con nombre de guerra de religión, guio sus huestes contra los moros». Y así pusieron a España en camino de «exceder en intolerancia religiosa a todas las naciones». ${ }^{80}$

En un artículo de 1860, Práxedes Mateo Sagasta atribuyó la «lamentable postración intelectual de España» (ese «atraso espantoso que nos colocó a tal distancia de los demás países que causa vergüenza el pensarlo») al triunfo del catolicismo «estacionario, intolerante y perseguidor» en los albores de la Edad Moderna, cuando «España, por las circunstancias especiales en que se encontraba después de ocho siglos de horrible lucha contra los enemigos de la ley cristiana y con su sentimiento religioso en el más alto grado de exaltación», se entregó a la Inquisición y la escolástica para asegurar «intactas las creencias en cuya defensa había derramado tanta sangre».81

A finales de siglo, Unamuno lamentó la unión «entre el patriotismo y la religión» impuesta en España desde que «en los siglos de la Reconquista se hizo de la cruz un pendón de batalla y hasta un arma de combate, haciendo de la milicia una especie de sacerdocio». ${ }^{82}$ Y Ganivet escribió que «el fanatismo fue una reversión contra nosotros mismos, cuando terminó la Reconquista, de la furia acumulada durante ocho siglos de combate». ${ }^{83}$

Es cierto que una importante tradición (surgida tal vez en círculos progresistas, pero pronto difundida en los conservadores) hablaba de

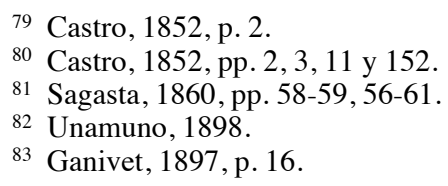


la «sublime tolerancia» de Alfonso $\mathrm{X}$ y otros reyes reconquistadores. ${ }^{84}$ Pero el consenso historiográfico decimonónico establecía que la tolerancia «de nuestros reyes y grandes señores» fue «menguando poco a poco conforme adelantaba la Reconquista, y conforme la civilización cristiana se sobreponía a la muslímica». ${ }^{85}$ También se decía que la tolerancia de los reyes de la Reconquista no fue muy del gusto de las masas cristianas. ${ }^{86}$ Los historiadores españoles del XIX atribuyeron casi siempre al «populacho» la intolerancia de la España medieval. Subrayaron la tensión entre ese «fanatismo popular» y la política regia «de tolerancia y protección». ${ }^{87} \mathrm{Y}$ vieron en la deriva intolerante de los Reyes Católicos y los Austrias una concesión a ese sentimiento popular «producto de las ideas que había dejado una lucha religiosa de ochocientos años». ${ }^{88}$

Balmes escribió que, lejos de deberse a la «voluntad de los reyes», la «intolerancia era popular» en la España moderna porque, «después de siglos de combates», no cabía esperar que los contendientes se portasen «con moderación y dulzura». ${ }^{89}$ El liberal Antonio Ferrer del Río (que, a diferencia de Balmes, sí contaba al «tribunal llamado Santo» entre los «males de España») coincidía con el sacerdote catalán en que la «popularidad de la intolerancia religiosa entre los españoles» era anterior a la Inquisición y en que los reyes de la casa de Austria fueron «protectores del Santo Oficio, bajo la influencia del mismo intolerante fervor que su pueblo»; un pueblo que «fue siempre ortodoxo, y que, habiendo luchado cerca de ocho siglos contra infieles, se exaltó más y más en la adoración de su fe nativa y en la intolerancia religiosa después del final triunfo». ${ }^{90}$

El arabista republicano Guillén Robles lamentó que la expulsión de los moriscos arrancase «a este país y a sus hogares millares de familias industriosas, con lo que se empobreció la riqueza de aquel tiempo y se comprometió la prosperidad en lo futuro». En su opinión, «la dulzura y la magnanimidad para

${ }^{84}$ Flórez Estrada, 1813, p. 95; Canga Argüelles, 1826, pp. 108-109; Amador de los Ríos, 1848, pp. 23-26; Janer, 1857, pp. 9 y 113-116; Amador de los Ríos, 1875, t. I, pp. 174-175; Menéndez Pelayo, 1880, v. I, p. 628.

85 Llorente, 1822, v. I, pp. 157 y 159; Valera, 1872, pp. 157-158; Tapia, 1840, Vol. I, p. 225 y v. II, p. 302; Lafuente, 1852, v. IX, pp. 205, 215 y 217; Hefele, 1860, 294-301; Danvila y Collado, 1889, p. 39; Zamora y Caballero, 1874, v. III, p. 163.

${ }^{86}$ Southey, 1811, pp. 327-328.

87 Tapia, 1840, v. I, pp. 225-227; Amador de los Ríos, 1876, v. II, pp. 152 y 201.

${ }^{88}$ Lafuente, 1852, v. IX, pp. 218, 416 y 419.

89 Balmes, 1842, v. II, pp. 302, 313, 340-341 y 380.

90 Ferrer del Río, 1856, t. I, pp. 71-72; Ferrer del Río, 1863, pp. 9-10. 
con los vencidos» habrían podido amalgamar a moriscos y cristianos «en bien del porvenir de nuestra nación». Pero los «odios históricos» heredados de la Reconquista «lo hicieron imposible», empujando a los dirigentes de la Monarquía Hispánica a colmar «las aspiraciones de las clases populares españolas»:

«Vencedoras y ensoberbecidas por sus triunfos, pretendían estas imponer su voluntad a los desdichados vencidos; enconadas por las luchas que contra ellos sostuvieron y por las desgracias que les habían costado sus victorias, les aborrecían mortalmente, y más que amantes, fanáticas por su religión, estimaban dignos de los más crueles suplicios, fuera de la ley común y hasta de la humanidad, a los que no querían bautizarse». ${ }^{91}$

Por lo general, la historiografía sobre los moriscos presentó su extrañamiento final como el desenlace de una guerra de siglos entre «dos razas enemigas». ${ }^{92}$ Dánvila y Collado veía en la expulsión de los moriscos la «consecuencia precisa de una Reconquista que había durado más de siete siglos» y «llevaba en su esencia la destrucción del enemigo y la unidad de la fe y de las creencias». Admitía que el desenlace de aquella guerra «de exterminio de raza contra raza» contribuyó «a la despoblación de España», «redundó en perjuicio de nuestra agricultura» y perjudicó «mucho el comercio». Pero celebraba el definitivo triunfo de «la unidad religiosa en 1609» como la más prudente solución a la larga «guerra de religión que comenzó con la Reconquista».93

Para el republicano Luis Morote, la Inquisición era resultado de «un espíritu de intolerancia obra del siglo, producto de una lucha religiosa de ochocientos años» y «causa de nuestra decadencia y ruina». Él también veía la unidad religiosa como el «obligado corolario» de una larga «guerra de razas contra judíos, mahometanos, judíos y herejes». Pero, lejos de alabarla, deploraba sus «horribles frutos»: «guerras civiles, muertes, daños, asolamientos, despoblación» y, en fin, el «continuo minar de nuestro poder hasta llegar a la presente ruina». ${ }^{94}$

Hubo, en definitiva, un amplio consenso en torno a la relación entre la política intolerante de los Austrias y la «guerra sin tregua de ocho siglos» que llenó a los españoles de odio y temor a los enemigos de su fe..$^{5}$ Manuel

\footnotetext{
91 Guillén Robles, 1880, pp. 365-366.

92 Janer, 1857, pp. 9 y 113-116.

93 Danvila y Collado, 1889, pp. 78, 29, 342 y 344.

94 Morote, 1900, pp. 155-156, 163.

95 García Tassara, 1839, p. 4.
} 
Suárez Cortina ha dicho últimamente que, en el siglo XIX, progresistas y republicanos «vieron en la pluralidad, o al menos en la tolerancia religiosa, el elemento que identificaba a España como nación». ${ }^{66}$ Yo creo, sin embargo, que los textos de la época no reflejan esa idea. La historiografía republicana y progresista recordó con frecuencia las protestas suscitadas por el establecimiento de la Inquisición, pero las atribuyó casi siempre a una minoría de escritores, nobles y conversos. ${ }^{97} \mathrm{Y}$ asumió que dicho establecimiento (fruto de los «clamores del ignorante vulgo» o de las «imposiciones de las masas exaltadas») «halagaba en general el carácter español». ${ }^{98}$

De hecho, los republicanos lamentaron más que nadie el «espíritu de intolerancia del pueblo español». ${ }^{99}$ Es verdad que, para Emilio Castelar, la nación no era «tan intolerante» como se decía, ya que, hasta el siglo XIV, «el principio de tolerancia religiosa reinaba imperfectamente» en ella. ${ }^{100}$ Pero, la historiografía republicana no idealizó en exceso la «convivencia de credos» en los reinos de la Reconquista. ${ }^{101}$ Más bien juzgó «inveterado el odio de los cristianos españoles a la raza judaica» y asumió que los mudéjares vivieron a veces amparados «por la tolerancia de los monarcas y en otras ocasiones perseguidos y maltratados». ${ }^{102}$

En pleno Sexenio Democrático, el krausista Alfonso Moreno Espinosa atribuyó a la Reconquista la fusión del «sentimiento religioso y el sentimiento patriótico» por la que «el catolicismo, ligando su suerte a la causa de la patria, fue luego un elemento constitutivo de nuestra nacionalidad y el más característico del pueblo español»..$^{103}$

Otro republicano, Juan Ortega Rubio, escribió al despuntar el siglo Xx:

«[P]or amor al ideal, luchamos a brazo partido en defensa de la causa cristiana con ardimiento que, si primero salvó de la barbarie musulmana la civilización occidental, a la postre nos convirtió en intolerantes y fanáticos y nos obligó a la comisión de errores políticos y económicos sin cuento». ${ }^{104}$

96 Suárez Cortina, 2017, pp. 377.

97 Llorente, 1812; 1822, pp. 26-27; Argüelles, 1826, p. 112; Moreno y Espinosa, 1871, pp. 214-215; Ortega Rubio, 1889, v. I, p. 452; Altamira, 1902, v. II, pp. 413-414 y 467

98 Moreno Espinosa, 1871, p. 229; Ugarte, 1877, p. 5; Muro, 1898, pp. 267.

99 Ortega Rubio, 1909, v. IV, p. 277.

100 Discursos de Emilio Castelar, Diario de Sesiones de las Cortes Constituyentes, 7 y 12 de abril de 1869 , pp. 900 y 989.

101 Suárez Cortina, 2017, pp. 385.

102 Ortega Rubio, 1889, v. I, p. 450; Muro, 1898, pp. 274-275.

103 Moreno Espinosa, 1871, p. 72.

104 Ortega Rubio, 1908, v. I, pp. XI-XII. 
Unos años antes, el también republicano Miguel Morayta se opuso a quienes justificaban el nacimiento de la Inquisición española como «una necesidad de los tiempos». Achacó al clero y a los reyes esta «causa única de la decadencia vergonzosa y terrible (...) de la cual no puede decirse del todo curada la España contemporánea». Y afirmó que, si bien la Inquisición tuvo en su origen muchos partidarios, «muchos eran también sus adversarios»: los judíos, los conversos, los nobles, las Cortes... Pero él mismo asumió que «la pérfida obra de la Inquisición» no fue una novedad radical, sino una exaltación de los sentimientos que constituían «el fondo del pueblo español», que «siempre creyó en su religión, en su monarca y en su honra» y que (desde que el «amor a su independencia nacional» lo «obligó a combatir durante siete siglos con los mahometanos») «odiaba al moro y el judío» y veía «un irreconciliable enemigo» en quien no compartiese sus creencias. ${ }^{105}$

Más aún: Morayta veía asomar ya en tiempos de Recaredo «la intolerancia, fatal y tristísima en todas partes, y desastrosa más que en ninguna en España» y lamentaba «los ríos de sangre y de oro que la costó, y aun las vergonzosas decadencias a que se vio tan constantemente reducida». ${ }^{106}$ En esto apenas se distinguía de liberales católicos como Lafuente, para quien ya se reveló «bajo el imperio de los godos el genio naciente de la Inquisición, cuyo férreo brazo había de pesar tan duramente sobre España». ${ }^{107}$

Por lo demás, la idea de la «coexistencia de credos» en la España medieval no fue exclusiva de los republicanos. En las Cortes de 1876, el diputado canovista José Fernández Jiménez asumió que la «muchedumbre unánime» había aplaudido las hogueras de la Inquisición como luego aplaudiría los «incendios del cantonalismo». Pero añadió que, en los siete siglos que «acrisolaron el carácter español» tras «la triste jornada de Guadalete», hubo una «constante coexistencia de tres religiones en España, sancionadas por las leyes, admitidas por las costumbres». Y concluyó: «la tolerancia es tan castiza y de tan rancio abolengo como el fervor católico». ${ }^{108}$

105 Morayta, 1894, v. III, pp. 61, 66, 1173.

106 Morayta, 1893, v. I, pp. 566-568.

107 Modesto Lafuente, 1850, v. I, pp. 55.

108 Discurso de José Fernández Jiménez, Diario de las Sesiones de Cortes. Congreso de los Diputados, 28 de abril de 1876, p. 987. 
Pero esa era entonces una opinión minoritaria. De principio a fin del siglo XIX, hasta quienes atribuían a los Austrias la deriva fanática de España solían admitir que, «después de una lucha de 800 años» contra los árabes, «quedó la nación española dotada de un carácter belicoso» y «enemigo de cuantos no profesaban la fe católica». ${ }^{109}$

\section{La Reconquista del carácter nacional}

En tiempos de los Austrias se decía que la Reconquista (llamada entonces Restauración) había reavivado en los españoles el humor guerrero y religioso heredado de Túbal. ${ }^{110}$ La historia crítica del siglo XVIII cuestionó el mito tubalino, pero insistió en que el temple originario de los españoles (adormecido por el influjo civilizador de griegos, fenicios y romanos) había resurgido en la lucha contra el árabe. ${ }^{11}$

En el siglo XIX, algunos historiadores interpretaron la Reconquista como la restauración del reino visigodo; otros, como la lucha de la raza íbera por su independencia. Martín Ríos ha vinculado la primera interpretación al moderantismo y la segunda al progresismo. ${ }^{112}$ Pero lo cierto es que muchos republicanos subrayaron la continuidad entre el reino de Toledo y el de Oviedo y muchos conservadores atribuyeron la Reconquista a la «primitiva raza española». ${ }^{113} \mathrm{Y}$ no faltó quien combinase ambas posturas afirmando que «la monarquía de los godos se restauró en Asturias» y recibió un nuevo «elemento de vida, de energía y de vigor» gracias a la «antigua raza» superviviente en las montañas. ${ }^{14}$

En cualquier caso, la idea de que la Reconquista reafirmó antiquísimos rasgos españoles sobrevivió intacta a la erudición decimonónica. De hecho, el auge del nacionalismo racialista no hizo más que reforzar esta vieja tesis. Ahora se hablaba menos de los descendientes de Túbal, y más

109 Alonso de Viado, 1813, p. 168.

110 Puente, 1612, lib. III, pp. 20, 21, 70, 153, 158 y 159; Garibay, 1628, v. I, pp. 325; Saavedra Fajardo, 1658, p. 518; Cortés Osorio, 1684, pp. 61, 67, 403, 408 y 420; Salazar y Mendoza, 1771, pp. 61-62 y 82-84; Fernández Albaladejo, 2007, p. 310; Ríos Saloma, 2011, pp. 5 y 73-74.

111 Wulff, 2003, pp. 40 y 90.

112 Ríos Saloma, 2011, pp. 328-329.

113 Morón, 1841, v. I, pp. 29 y 32; 1843, v. III, pp. 184-185; Amador de los Ríos, 1862, v. II, pp. 20, 22, 25 y 138; Ortega Rubio, 1889, v. I, p. 155; Morayta, 1893, v. I, p. 800.

114 Muñoz y Romero, 1856 , p. $3 ; 1860$, pp. 8 y 9. 
de los íberos, los celtas, la raza indígena... Pero aún se atribuía a los montañeses que iniciaron la Reconquista la misma «agreste ferocidad» con que Estrabón había adornado a los cántabros. ${ }^{115}$

Historiadores de las más diversas tendencias políticas coincidieron en presentar la Reconquista como el renacer de «los antiguos instintos guerreros de los primitivos pobladores». Amador de los Ríos escribió que en Covadonga retoñó, «para asombro de las edades, el antiguo valor de los iberos, probado contra Roma en una guerra de doscientos años, y que debía acrisolarse con cien y cien victorias, en una lucha de ocho siglos». ${ }^{116}$ Fabié dijo que «la guerra sostenida durante ocho siglos para lanzar de la Península a las tribus agarenas que quisieron importar costumbres, organización y tendencias de todo punto extrañas a las indígenas, ocasionó un apego tal a las antiguas instituciones» que los españoles, lejos de contagiarse de los árabes, «conservaron puro el tesoro de sus ideas y tradiciones». ${ }^{117}$ Danvila y Collado afirmó que «la raza hispánica» estaba dividida en «dos masas» desde la antigüedad: la de los pueblos meridionales y orientales, inundados de «cultura y adelantos sociales importados por los pueblos civilizados», y la de los «más belicosos» pueblos septentrionales que, alejados del influjo extranjero, conservaban «la barbarie y la rudeza primitiva». De ahí que, tras la invasión musulmana, la nación recobrase «su nativa fiereza» en las «agrestes montañas del Septentrión, donde siempre encontró respetado asilo la independencia española». ${ }^{118} \mathrm{El}$ «carácter ibero» volvió entonces a «su antigua fiereza»y, con ella, a «su ardor religioso», su «amor a la libertad» $\mathrm{y}$ «su instinto monárquico». ${ }^{119} \mathrm{Y}$ esos sentimientos, que «por espacio de ocho siglos» fueron «bandera de la Reconquista», formaron el «carácter nacional»y los elementos constitutivos de la «nacionalidad española»..$^{20}$

El krausista Eduardo Pérez Pujol consideró que la «antigua gente española» ya había recobrado sus «violentos hábitos» al entrar, durante el Reino visigodo, en «contacto con el espíritu germánico, de que era congénere». Y que, «en tiempos de Pelayo», el «elemento germánico» vol-

\footnotetext{
115 Lafuente, 1850, v. I, p. 299.

116 Amador de los Ríos, 1861, v. I, p. 469; 1862, v. II, p. 4.

117 Fabié, 1859, p. 8.

118 Danvila y Collado, 1885, v. I, pp. 38, 112 y 578.

119 Danvila y Collado, 1881, pp. 99, 194, 164, 223, 408-415 y 423-425.

${ }^{120}$ Danvila y Collado, 1885, v. I, pp. 224, 234 y 537, 560, 579-581.
} 
vió a mezclarse en las montañas con el «carácter enérgico, indisciplinado, fiero» de «las primitivas razas españolas». ${ }^{121}$

La Reconquista se presentó también como una cruzada que reavivó la ancestral religiosidad hispánica. Algunos reaccionarios continuaron repitiendo que «los principios de religión natural», importados por «Túbal, o por Tarsis, o por sus descendientes», permanecieron incólumes en España desde antiguo. ${ }^{122}$ Los partidarios de la «unidad católica» presentaban a la «raza ibérica» guardando «con la mayor veneración la fe y las costumbres de sus mayores», pese haber sido «uno de los pueblos que han sufrido más y más duraderas dominaciones». Y así explicaban por qué, frente a la «tolerancia de los árabes», los reconquistadores impusieron su religión y sus leyes «con la severidad y el exclusivismo de quien tiene en ellas fe ciega y convicciones profundas». ${ }^{123}$

Algunos republicanos culparon a la raza de un fanatismo español que suponían eterno. Para Luis Morote, ya los celtíberos mostraron el «modo de ser religioso de los españoles, aferrados a sus creencias, y por lo mismo intolerantes». Y la Inquisición, por tanto, no fue solo «consecuencia de las continuas luchas con los árabes, que identificaron la idea del patriotismo con la idea religiosa», sino el remate de una «obra de exterminio» milenaria. ${ }^{124}$

En su etapa más liberal y europeísta, la madrileña Revista contemporánea publicó un discurso del hispanista alemán Hermann Baumgarten sobre las causas religiosas de la distancia entre España y Europa. En él puede leerse:

«Comúnmente se atribuye el ardoroso celo por la religión del pueblo español al resultado de más de 700 años de sufrimientos, durante los cuales los cristianos de España lucharon con los moros invasores, extraños al país por su raza y creencias; pero anteriormente a esta gran epopeya religiosa, vemos aparecer la vehemencia propia del carácter español en las persecuciones que sufrieron los judíos y en la mutua enemistad de católicos y arrianos».

Baumgarten atribuye al suelo abrasador de la Península tanto ese «temperamento ardiente y vigoroso» como otras «cualidades inherentes al carácter español»: el orgullo, el desprecio del trabajo, el predomino de la imaginación sobre la inteligencia y el apasionamiento ruidoso. A la Re-

\footnotetext{
121 Pérez Pujol, 896, v. I, pp. 83-84 y v. II, pp. 60, 75 y 135.

122 Fuente, 1873, v. I, p. 27; Merry y Colón, 1876, v. I, p. 23.

123 Gómez de Arteche, 1868, v. I, pp. 8 y 9.

124 Morote, 1900, pp. 124, 126 y 155.
} 
conquista le asigna el papel de acrisolar ese carácter primigenio: las luchas contra los «moros» no propiciaron «la ilustración» ni «el trabajo pacífico»y, cuando la «luz» de la Reforma se extendió por Europa, el pueblo español se mantuvo al margen porque llevaba siglos asociando «el amor patrio y el odio por causa de fe» y siendo, en suma, «distinto de los demás pueblos del globo». ${ }^{125}$

\section{Conclusión}

Hasta ahora, la obsesión con la «leyenda negra» y las «dos Españas» ha impedido advertir que el gran mito identitario español (el de la lejanía de la modernidad europea) fue largamente compartido por progresistas y conservadores y por españoles y extranjeros. Por eso, aunque se han escrito muchas páginas sobre los relatos de la Reconquista, se ha insistido más en la variedad de esos relatos que en su unánime contribución al mito.

Los discursos sobre la Reconquista reforzaron la imagen de España como un país reñido con la industria, la ciencia y (en especial) la tolerancia religiosa; una imagen que no solo compartían los críticos del pasado español, sino también sus más entusiastas defensores.

Aquí me he centrado en el siglo XIX, pero el mito mantuvo su vigencia en el Xx. En la exaltación franquista de Pelayo y Covadonga. En las críticas de la izquierda al fanatismo reconquistador. Y en la historia profesional de Menéndez Pidal o Sánchez-Albornoz, que siguió contando la Reconquista como el renacer de la «España eterna»: violenta, aventurera, irracional y fanática.

\section{Bibliografía}

«ADICIONES AL ARTíCULO ESPAÑA», Enciclopedia metódica. Geografía moderna, Sancha, Madrid, 1792, v. II, pp. 100-106.

AlONSO DE ViAdO, Manuel, «Historia de la literatura española, escrita en alemán

por Mr. Bouterwek», Gaceta de Madrid, 11 de febrero de 1813, pp. 166-168.

Altamira, Rafael, Historia de España y de la civilización española. Tomo II, Juan Gili, Barcelona, 1902.

Altamira, Rafael, Los elementos de la civilización, Losada, Buenos Aires, 1950.

125 Baumgarten, 1877, pp. 431-452. 
Álvarez Junco, Mater Dolorosa: la idea de España en el siglo XIX, Taurus, Madrid, 2001.

Álvarez Junco, José y Fuente Monge, Gregorio de la, El relato nacional. Historia de la historia de España, Taurus, Madrid, 2017.

AMADOR DE LOS Ríos, José, «Apuntes sobre la influencia de los árabes en las artes y literatura españolas», La floresta andaluza, 7 de agosto de 1843, pp. 150-152.

AMADOR DE LOS Ríos, José, Estudios históricos, políticos y literarios sobre los judíos de España, Díaz y comp. , Madrid, 1848.

AMADOR DE LOS Ríos, José, Historia social, política y religiosa de los judíos de España y Portugal, T. Fortanet, Madrid, 1876.

AMADOR DE LOS Ríos, José, Historia crítica de la literatura española, José Rodríguez, Madrid, 1861-1865.

Andreu Miralles, Xavier, El descubrimiento de España: Mito romántico e identidad nacional, Taurus, Madrid, 2016.

Arroyal, León, Cartas económico-políticas, Universidad de Oviedo, Oviedo, 1971.

BALMES, Jaime, El protestantismo comparado con el catolicismo, José Taulo, Barcelona, 1842-1844.

BAumgaRTEN, Hermann, «El desenvolvimiento religioso de España», Revista Contemporánea, IX, 1877, pp. 430-452.

BAUZÁ, Francisco, Historia de la dominación española en el Uruguay, Barreiro y Ramos, Montevideo, 1895.

Blanco White, José María, «Bosquejo de la Historia del entendimiento en España desde la restauración de la literatura hasta nuestros días u Opresión del entendimiento en España», Variedades o El mensajero de Londres, 1 de enero de 1824, pp. 104-120.

Blanco White, José María, «El Alcázar de Sevilla», No me olvides, R. Ackermann, Londres, 1825, pp. 4-27.

BouTERWECK, Friedrich, Geschichte der Poesie und Beredsamkeit, Johann Friedrich Röwe, Göttingen, 1805.

CAdAlso, José, Cartas marruecas, Sancha, Madrid, 1793.

CANga ArgüElles, José, Ensayo sobre las libertades de la iglesia española en ambos mundos, M. Calero, Londres, 1826.

Cánovas del Castillo, Antonio, Historia de la decadencia de España desde el advenimiento al trono de D. Felipe III hasta la muerte de Don Carlos II, Establecimiento Tipográfico del Semanario Pintoresco Español, Madrid, 1854.

Cánovas del Castillo, Antonio, «Contestación», en Discursos leídos ante la Real Academia de la Historia en la recepción pública de don Emilio Lafuente y Alcantara, Manuel Galiano, Madrid, 1863, pp. 45-65.

Cánovas del CASTILlo, Antonio, «Del principio y fin que tuvo la supremacía militar de los españoles en Europa», Revista de España, 1, 1868, pp. 151-204.

Cánovas del Castillo, Antonio, De la casa de Austria en España, Biblioteca Universal Económica, Madrid, 1869. 
¿Patriotismo o leyenda negra? La Reconquista en el siglo XIX

CAÑIZAREs-Esguerra, Jorge, Nature, Empire, and Nation: Explorations of the History of Science in the Iberian World, Stanford University Press, Stanford, 2006.

CAPPA, Ricardo, La Inquisición española, Antonio Pérez Dubrull, Madrid, 1888.

CASTElAR, Emilio, La cuestión de Oriente, La Ilustración Española y Americana, Madrid, 1876.

CASTRo, Adolfo de, Examen filosófico sobre las principales causas de la decadencia de España, Francisco Pantoja, Cádiz, 1852.

CASTRo, Federico de, «Prólogo del traductor», en Reinhart Dozy, Historia de los musulmanes españoles hasta la conquista de Andalucía por los almorávides (711-110), Victoriano Suarez, Madrid, 1877, pp. V-XXIX.

«COMEntarios al Concordato», La España, 29 de mayo de 1851, p. 2.

Cevallos, Fernando de, La falsa filosofía. Tomo sexto, Antonio Fernández, Madrid, 1776.

Conte Lacave, Augusto, La Leyenda negra en la primera mitad del siglo XIX, Imprenta Ordóñez, Cádiz, 1923.

CORTÉs OsORIO, Juan, Constancia de la fe y aliento de la nobleza española, Antonio Román, Madrid, 1684.

Danvila y Collado, Manuel, Libertades de Aragón, Fortanet, Madrid, 1881.

Danvila y Collado, Manuel, El poder civil en España, Manuel Tello, Madrid, 1885-1886.

Danvila y Collado, Manuel, La expulsión de los moriscos españoles, Fernando Fe, Madrid, 1889.

DomíngueZ, Juan Pablo, «España contra las luces: antiilustrados, apologistas y el triunfo de la leyenda negra (1759-1808)», Bulletin of Spanish Studies, 96, 2019, pp. 219-240.

DomíngueZ, Juan Pablo, «La idea de España en el discurso «servil» (18081814)», Historia y política 41, 2019, pp. 177-209.

Escolano, Gaspar, Segunda parte de la década primera de la historia de la insigne, y coronada ciudad y reino de Valencia, Pedro Patricio Mey, Valencia, 1611.

ESTRADA, José Manuel, Lecciones sobre la historia de la República argentina, Colegio de Pedro Igón y Cía, Buenos Aires, 1896.

FABí́, Antonio María, «De los más notables acontecimientos que tuvieron lugar en España durante los siglos XVI y XVII», La América, 24 de enero de 1859, pp. 7-8.

FERrer Del Río, Antonio, Historia del reinado de Carlos II en España, Matute y Compagni, Madrid, 1856.

FERRER DEL Río, Antonio, Apuntes contra la titulada vida de Jesús, de Mr E. Renan, Imprenta Nacional, Madrid, 1863.

Fernández Albaladejo, Pablo, Materia de España, Marcial Pons, Madrid, 2007.

Fernández Valcarce, Vicente, Desengaños filosóficos. Tomo Cuarto, Blas Román, Madrid, 1797. 
FlóRez EstradA, Álvaro, «Observaciones sobre la que se titula Carta Pastoral de los RR. Obispos refugiados en Mallorca», El Tribuno del Pueblo Español, 4 de junio de 1813,pp. 89-97

Forner, Juan Pablo, «Discurso sobre el amor de la patria», en Obras, La Amistad, Madrid, 1844, pp. 201-231.

Forneron, Henri, Histoire de Philippe II, E. Plon et Cie, Paris, 1881-1882.

FuEnte, Vicente de la, Historia eclesiástica de España, Compañía de impresores y libreros del reino, Madrid, 1873.

GANIVET, Ángel, Idearium español, Viuda e Hijos de Sabatel, Granada, 1897.

GANIVET, Ángel, «El provenir de España. I», El Defensor de Granada, 9 de julio de 1898,p. 1.

García TAssara, Gabriel, «Moriscos y cristianos», El Correo nacional, 2 de julio de 1839, p. 4.

GARIBAY, Los cuarenta libros del compendio historial, Sebastián de Cormellas, Barcelona, 1628.

GAsCón PÉRez, Jesús, «Antonio Ferrer del Río y las comunidades de Castilla en el siglo de la Historia», en Antonio Ferrer del Río, Historia del levantamiento de las comunidades de Castilla, 1520-1521, Urgoiti Editores, Pamplona, pp. IX-LXXIII.

GeBhaRdT, Víctor, Historia de España y de sus Indias, Luis Tasso, Barcelona, 1864.

Gómez de ARTEChe, José, Guerra de la Independencia. Historia Militar de España de 1808 a 1814, Imprenta del Crédito Comercial, Madrid, 1868.

GRAEF, Enrique, «Discurso preliminar», Discursos mercuriales, I, 1 de octubre de 1755, pp. 1-72.

GuILlÉn RoBles, Francisco, Málaga musulmana, M. Oliver Navarro, Málaga, 1880.

Hefele, Karl Joseph von, The Life and Times of Cardinal Ximenez, Catholic Publishing \& Bookselling Company, London, 1860.

IAROCCI, Michael, Properties of Modernity: Romantic Spain, Modern Europe, and the Legacies of Empire, Vanderbilt University Press, Nashville, 2006.

IRIARTE, Tomás de, Obras sueltas de D. Juan de Iriarte, D. Francisco Manuel de Mena, Madrid, 1774, t. II, pp. 240-247.

JAKsić, Iván, Ven conmigo a la España lejana, Fondo de Cultura Económica, México, 2007.

JANER, Florencio, Condición social de los moriscos de España, Real Academia de la Historia, Madrid, 1857.

JUDERÍAS, Julián, La leyenda negra y la verdad histórica, Tip. de la Revista de Archivos, Madrid, 1914.

Juliá, SAntos, Historia de las dos Españas, Taurus, Madrid, 2004.

LAFUENTE, Modesto, Historia general de España, Mellado, Madrid, 1850-1869.

LAMPILlaS, Francisco Javier, Ensayo histórico-apologético de la literatura española. Tomo Segundo, Blas Miedes, Zaragoza, 1783. 
LEA, Henry Charles «The decadence of Spain», The Atlantic Monthly, July 1989, pp. 36-46.

LlORENTE, Juan Antonio, Memoria histórica sobre cuál ha sido la opinión nacional de España acerca del tribunal de la Inquisición, Sancha, Madrid, 1812.

Llorente, Juan Antonio, Historia crítica de la Inquisición de España, Imprenta del Censor, Madrid, 1822.

LÓPEZ VELA, Roberto, «Inquisición, protestantes y Felipe II en 1851. Adolfo de Castro y la historia nacional como leyenda negra», Cuadernos de Ilustración y Romanticismo 13, 2005, pp. 171-199.

«Los nietos De Pelayo», El Fígaro, 9 de septiembre 1918, p. 5.

Macaulay, Thomas Babington, Critical and Historical Essays, Longman, Brown, Green and Longmans, London, 1843.

Macías PiCAVEA, Ricardo, El problema de España, Victoriano Suárez, Madrid, 1899.

MARTíneZ DE IRUJO Y DEL AlCÁZAR, Carlos «La libertad de enseñanza», Revista Mensual, 3, 1868, pp. 283-296.

MARTínEZ DE LA RosA, Francisco, «El sentimiento religioso», Revista de Madrid, II, 1841, pp. 313-322.

Masdeu, Juan Francisco, Historia crítica de España y de la cultura española, Sancha, Madrid, 1783-1805.

MENDíBIL, Pablo, «Apéndice a la historia de los árabes en España: rebeliones y expulsiones de los moriscos», Ocios de españoles emigrados, 28, julio de 1826, pp. 61-75.

MenÉndez Pelayo, Marcelino, Historia de los heterodoxos españoles, F. Maroto e Hijos, Madrid, 1880.

Mesonero Romanos, Ramón de, «Las costumbres de Madrid», en Cartas españolas, I. Sancha, Madrid, 1832, t. V, pp. 10-13.

Merry y Colón, Manuel, Historia de España, A. Izquierdo, Sevilla, 1876-1884.

MorA, José Joaquín de, Leyendas españolas, C. y H. Senior, Londres, 1840.

Morayta, Miguel, Historia general de España, Felipe González Rojas, Madrid, 1893-1898.

MoRel, Jules, Inquisition et libéralisme, Cosnier et Lachèse, Angers, 1857.

Moreno Espinosa, Alfonso, Compendio de historia de España, Imp. de la Revista Médica, Cádiz, 1871.

Morote, Luis, La moral de la derrota, Estab. Tip. de G. Juste, Madrid, 1900.

Morón, Fermín Gonzalo, Curso de historia de la civilización de España, Alegría y Charlain, Madrid, 1841-1846.

MoRón, Fermín Gonzalo, «Examen histórico-filosófico sobre el antiguo teatro español», Revista de España y del Extranjero, 4, 1842, pp. 132-144.

MoRón, Fermín Gonzalo, «Exposición y juicio del sistema administrativo desde 1808 a 1814», Revista de España y del extranjero, 1844, v. VIII, pp. 145-154.

Muro, José, Compendio de Historia de España, Hijos de J. Pastor, Valladolid, 1898. 
MuÑoz y Romero, Tomás, Del estado de las personas en los reinos de Asturias y León en los primeros siglos posteriores a la invasión de los árabes, 1856.

Muñoz y Romero, Tomás, Discursos leídos ante la Real Academia de la Historia, M. Rivadeneyra, Madrid, 1860.

Ortega Rubio, Juan, Compendio de historia de España, Hijos de Rodríguez, Valladolid, 1889.

Ortega Rubio, Juan, Historia de España, Bailly-Bailliere, Madrid, 1908-1910.

Palma, Clemente, El porvenir de las razas en Perú, Torres Aguirre, Lima, 1897.

PASARÓN LASTRA, Ramón, «Influjo del descubrimiento de América en los intereses materiales de la Península hasta fines del último siglo», La América, 8 de noviembre de 1857 , p. 10.

Pellicer, José, Defensa de España contra las calumnias de Francia, Venecia, 1635.

Rodríguez de CAMPOMANES, Pedro, Discurso sobre la educación popular de los artesanos y su fomento, Antonio Sancha, Madrid, 1875.

PÉReZ-Magallón, Jesús, «Apologías, identidad nacional y el desplazamiento de España a la periferia de la Europa «moderna» », en José Checa Beltrán (ed.), Lecturas del legado cultural español, Iberoamericana Vervuert, Madrid, 2012, pp. 13-40.

PÉrez Pujol, Eduardo, Historia de las instituciones sociales de la España goda, F. Vives Mora, Valencia, 1896.

PÉREZ VEJo, Tomás, «El relato de nación de la Restauración canovista: una aproximación iconográfica», en María Cruz Romero Mateo, Pilar Salomón y Nuria Tabanera (coords.), De relatos e imágenes nacionales: las derechas españolas (siglos XIX-XX) Zaragoza, Prensas de la Universidad de Zaragoza, 2020, pp. 41-64.

PICAVEA, Macías, El problema nacional, Victoriano Suárez, Madrid, 1899.

PIDAL, Pedro José, La unidad católica en España, Roque Labajos, Madrid, 1875.

PITRA, Jean-Baptiste, Histoire de Saint L'Eger, Waille, Paris, 1846.

Polo y Peyrolón, Manuel, Ligera exposición doctrinal del credo católico tradicionalista, Manuel Alufre, Valencia, 1904.

Premo, Bianca, The Enlightenment on Trial: Ordinary Litigants and Colonialism in the Spanish Empire, Oxford University Press, New York, 2017.

Puente, Juan de la, La conveniencia de las dos monarquías católicas, Imprenta Real, Madrid, 1612.

PrescotT, William H., History of the Reign of Ferdinand and Isabella, the Catholic, American Stationers' Company, Boston, 1838.

Prescott, William H., The Reign of Philip the Second, King of Spain, Phillips, Sampson and Company, Boston, 1856-1858.

Ranke, Leopold von, The Ottoman and the Spanish Empire, Lea \& Blanchard, Philadelphia, 1845.

REDONDO, Patricio, En boca cerrada no entra mosca, s. n, s. 1.

RIVERA, Mariano, «Advertencia del traductor», en Antonio Cavanilles, Observaciones sobre el artículo España, Imprenta Real, Madrid, 1784. 
Ríos Saloma, Martín F., La Reconquista: una construcción historiográfica (siglos XVI-XIX), Marcial Pons, Madrid, 2011.

Roca BAREA, María Elvira, Imperiofobia y leyenda negra, Siruela, Madrid, 2017.

RoBERTSON, William, The History of the Reign of the Emperor Charles V, W. and W. Strahan, London, 1769.

Rodríguez Mohedano, Rafael y Rodríguez Mohedano, Pedro, Historia literaria de España. Tomo I, Antonio Pérez de Soto, Madrid, 1766.

Rodríguez PinILla, Tomás, Notas del traductor, en François Laurent, Historia de la humanidad, Marcelino Bordoy y Ca., Barcelona, 1879, v. II, pp. 3-292.

SaAvedra Fajardo, Diego, Corona Gótica, Andrés García de la Iglesia, Madrid, 1658.

SAGASTA, Práxedes Mateo, «Las universidades», Almanaque político y literario de la Iberia, La Iberia, Madrid, 1860, pp. 56-61.

Salazar, Juan de, Política española, Diego Mares, Logroño, 1619.

SAlazAr y Mendoza, Pedro de, Monarquía de España, Ibarra, Madrid, 1771.

SAlgAdo, Miguel Antonio, «Dictamen», en José Marín, La debilidad de los espíritus fuertes, Domingo Casero, Salamanca, 1778.

Schlegel, August Wilhelm von, A Course of Lectures on Dramatic Art and Literature, Baldwin, Cradock and Joy, London, 1815.

Schlegel, Friedrich, Philosophie der Geschichte, Carl Schaumburg und Compagnie, Wien, 1829.

SchwarTZ, Stuart B., All can be Saved: Religious Tolerance and Salvation in the Iberian Atlantic World, Yale University Press, New Haven, 2008.

SIMONET, Francisco Javier, «Examen de libros», La ciencia cristiana, XI, 1879, pp. 69-77.

SouTHEY, Robert, «Tracts on the Spanish and Portuguese Inquisitions», The Quarterly Review, December 1811, pp. 313-357.

SuÁrez Cortina, Manuel, «Religión, Estado y Nación en España y México en el siglo XIX: una perspectiva comparada», Historia mexicana, 67, 2017, pp. 341-400.

TAPIA, Eugenio de, Historia de la civilización española, Yenes, Madrid, 1840.

TORRECILLA, Jesús, Guerras literarias del XVIII español: la modernidad como invasión, Universidad de Salamanca, Salamanca, 2009.

Torrecilla, Jesús, España al revés: los mitos del pensamiento progresista (1790-1840), Marcial Pons, Madrid, 2016.

Tubino, Francisco María, Estudios sobre el arte en España, C. Segovia de los Ríos, Sevilla, 1886.

UGARTE, Eliano, Nota del traductor, en Hermann Baumgarten, «El desenvolvimiento religioso de España», Revista Contemporánea, IX, 1877, p. 434.

Unamuno, Miguel de, «El porvenir de España. V», El Defensor de Granada, 31 de julio de 1898 , p. 1.

VAlerA, Juan, «N. del T.», en Adolf Friedrich von Schack, Poesía y arte de los árabes en España y Sicilia, M. Ribadeneyra, Madrid, 1872, t. III, pp. 157-159. 
VeUILLOT, Louis, «L'Europe en Asie», Mélanges religieux, historiques, politiques et littéraires, Gaume Frères et J. Duprey, Paris,1860, v. 4, pp. 153-196.

VILLERS, Charles de, Essai sur l'esprit et l'influence de la réformation de Luther, Henrich, Paris, 1804.

Voltaire, Essay sur l'Histoire Générale, Cramer, Genève, 1756-1761.

WALSH, William Thomas, Isabella of Spain, the Last Crusader, R. M. McBride \& Company, New York, 1930.

WulfF, Fernando, Las esencias patrias, Crítica, Barcelona, 2003.

ZAMORA Y CABALLERO, Eduardo, Historia general de España y de sus posesiones de ultramar, La Ilustración Universal, Madrid, 1874.

\section{Datos del autor}

Juan Pablo Domínguez licenciado en Historia por la Universidad de Navarra (2005) y doctor en Historia por la misma universidad (2010). Su tesis obtuvo en 2011 el Premio de la Real Academia de Doctores. Ha sido postdoctoral fellow del Council for Latin American and Iberian Studies de la Universidad de Yale y visiting scholar del Modern European History Research Centre de la Universidad de Oxford. Actualmente trabaja como investigador del proyecto Religión y Sociedad Civil del Instituto Cultura y Sociedad (ICS) de la Universidad de Navarra. Ha publicado más de diez artículos en prestigiosas revistas académicas de España y Reino Unido y ha editado un número monográfico de History of European Ideas. Sus investigaciones giran, casi siempre, en torno al ideal ilustrado de tolerancia y a la idea de España como antítesis de la modernidad. 